\title{
SPOKOJENOST ZÁKAZNÍKA V KONTEXTU PODNIKŮ CESTOVNÍHO RUCHU
}

\section{Lenka Půlpánová}

\section{Klíčová slova:}

spokojenost zákazníka, cestovní ruch, cestovní kancelář, kvadrantová analýza

\section{Key words:}

customer satisfaction, tourism, travel agency, quadrant analysis

\begin{abstract}
Abstrakt
Cestovní ruch je odvětví s vysokou konkurencí. Zejména v České republice počet cestovních kanceláŕí od roku 2004 neustále roste. Aby se podniky udržely na trhu, měly by se zaměřit na analýzu spokojenosti zákazníků. Nestačí však pouze znát, s jakými atributy jsou zákazníci nejvíce, resp. nejméně spokojení. Pro cestovní kanceláře a agentury je velmi podstatné zohlednit $\mathrm{i}$ aspekt důležitosti, tj. zda daný atribut, s kterým je zákazník nespokojený, je pro něho důležitý či nikoliv. Podle toho by pak firmy měly alokovat svoje zdroje za účelem zlepšení výkonnosti. Článek proto představuje činnost cestovních kanceláŕí a agentur na českém trhu a shrnuje výsledky výzkumu zaměřeného na spokojenosti zákazníka formou kvadrantové analýzy.
\end{abstract}

\begin{abstract}
Tourism industry is characterised by high level of competition. Particularly in the Czech Republic, the number of travel agencies has been constantly growing since 2004. The companies should focus on the analysis of customer satisfaction in order to succeed in this market. It is not sufficient to know with which attributes the customers are more or less satisfied. It is essential to take the importance into consideration, i.e. whether the attribute with which customers are not satisfied, is also important for them or not, and in accordance with this to allocate the resources in order to improve the performance. Therefore, this article introduces the activity of travel agencies and tour operators in the Czech market and summarizes in the form of quadrant analysis the results of the research that focused on the customer satisfaction.
\end{abstract}

\section{Úvod}

Jelikož cestovní ruch patři $\mathrm{k}$ důležitým odvětvím z globálního i regionálního pohledu, je podstatné tento trh analyzovat a porozumět mu. Z pohledu nabídky cestovního ruchu hrají v České republice důležitou roli cestovní kanceláře $(\mathrm{CK})$ a cestovní agentury $(\mathrm{CA})$. Počet CK se od roku 2004 zvýšil o 47 \% [11]. V porovnání s ostatními evropskými zeměmi je v tomto směru český trh cestovního ruchu vysoce nasycen a udržet se na něm mohou jen podniky, které jsou konkurenceschopné a které dokáží uspokojit a udržet si své zákazníky. Proto by se měly soustředit na analýzu spokojenosti.

Hlavním důvodem pro sledování spokojenosti zákazníků je skutečnost, že spokojenost zákazníků má dopad na finanční výsledky firmy. Organizace očekávají od svých klientů opakované nakupování a předpokládají příliv nových zákazníků, což přináší zvýšení prodeje a zisku a v důsledku toho i růst tržního podílu a konkurenční pozice. Bylo prokázáno, že pro firmy je ekonomicky výhodnější udržet si stávající zákazníky, než-li získávat nové, protože firma tím ušetři marketingové náklady spojené s akvizicí nových zákazníků. Navíc bylo 
zjištěno, že spokojený zákazník sdělí svoji pozitivní zkušenost obvykle 4 - 5 jedincům, zatímco o svoji negativní zkušenost se nespokojený zákazník podělí s 9 - 10 lidmi $[3,6]$. Cílem článku je proto identifikovat atributy spokojenosti, které jsou pro zákazníky důležité a posoudit i jejich spokojenost s nimi. Na tyto atributy by se pak CK a CA měly zaměřit za účelem zvýšení své konkurenceschopnosti.

\section{Cestovní kanceláře a agentury - zprostředkovatelé na trhu cestovního ruchu}

Z pohledu individuální poptávky je třeba podotknout, že zákazník využije některé služby (produkty), které jsou nabízeny různými subjekty v oblasti nabídky cestovního ruchu, ale celkově vnímá služby jako integrovaný výkon (viz obr. 1). Tomuto pocitu zákazníka velmi napomáhá fakt, že si služby zakoupí jako jeden „balíček“ u zprostředkovatelů cest, tj. cestovních kanceláŕí a agentur.

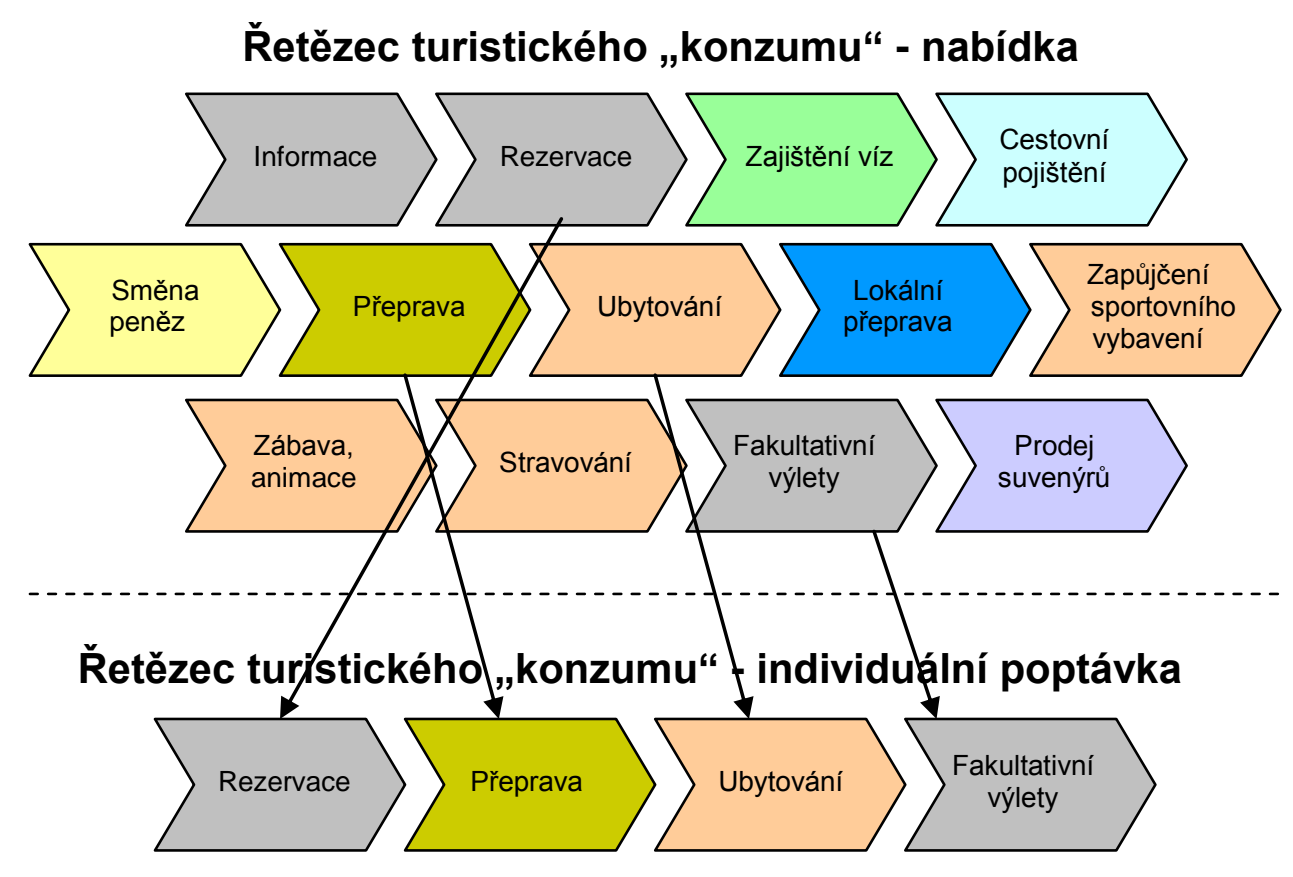

Obr. 1: Turistická nabídka versus poptávka. Vlastní zpracování.

Zákazník tedy definuje prostřednictvím volby svých aktivit sít' podniků, která optimálně spolupracuje pro zvýšení spokojenosti zákazníka a obhospodařuje za tímto účelem společné zdroje. Tato sít' se tak stává virtuálním podnikem. Typický je tento proces tvorby virtuálních podniků právě pro cestovní ruch, kdy zákazník spotřebovává elementy služeb, které si sám sestavil, čímž se stává tato oblast velice komplexní pro analýzu spokojenosti zákazníka [1].

Je třeba zdůraznit, že CK se od CA liší v tom, že CK je na základě koncese oprávněna nabízet a prodávat zájezdy a je povinna uzavřít pojištění proti úpadku, zatímco CA spadá do živností volných a je oprávněna nabízet a prodávat jednotlivé služby cestovního ruchu [9]. Zájezd je definován Zákonem č. 159/1999 Sb. a rozumí se jím kombinace alespoň dvou služeb (doprava, ubytování a doplňkové služby) [10]. Dle výzkumu Ministerstva pro místní rozvoj (MMR), který provedla společnost Incoma GfK, bylo zjištěno, že pouze 44 \% Čechů rozlišuje mezi CK a CA, ačkoli je mezi těmito dvěma organizacemi značný rozdíl mající významný dopad na spotřebitele zejména při zániku CK, resp. CA [7]. 
Existence služeb CK a CA přináší mnoho výhod třem skupinám subjektů. První skupinu tvoří subjekty nabídky cestovního ruchu (jednotliví poskytovatelé služeb), kteří získávají tyto výhody:

- prodávají ve velkém a přenášejí tak riziko na zprostředkovatele, ačkoli se zprostředkovatelé snaží jistit různými smlouvami a výjimkami,

- snižují náklady na komunikaci, pokud se zaměří na zprostředkovatele spíše než na komunikaci se zákazníkem, která je mnohem dražší.

Druhou skupinou jsou zákazníci CK a CA, kteří využívají jejich služeb zejména proto, že:

- se vyhnou nákladům na hledání a vyjednávání z hlediska času i peněz, pokud si koupí kompletní zájezd,

- těží ze specifických znalostí tour operátora a z faktu, že je minimalizována nejistota cesty,

- často těží z nižších cen, zejména $\mathrm{v}$ případě rezortů s velkým počtem návštěvníků (v takových destinacích získají CK díky své kupní síle slevy až 60 \% oproti běžným cenám).

Třetí skupinou jsou destinace. Obzvláště v rozvojových zemích s omezenými rozpočty mohou mít destinace významnou výhodu z mezinárodní marketingové spolupráce tour operátorů [2].

Samozřejmě existuje i řada nevýhod. Jednotlivým poskytovatelům služeb se snižuje při spolupráci se zprostředkovateli marže, kontrola nad marketingovými aktivitami a rovněž vliv na distribuční proces. Vyšší koncentrace a slučování zprostředkovatelů může zákazníkovi ve skutečnosti omezit výběr a zvýšit ceny. Pokud se destinace stanou př́liš závislé na rezervacích zprostředkovatelů, snáze podlehnou výkyvům trhu a schopnosti zprostředkovatelů ovlivnit výběr zákazníka tím, že mu nabídnou výnosnější destinaci [2].

I přes výše uvedené nevýhody se počet $\mathrm{CK}$ a CA v ČR v posledních letech zvyšuje, přičemž růst nebyl ovlivněn ani ekonomickou krizí. Statisticky je evidován pouze počet $C K$ a to hlavně z důvodu počtu vydaných koncesí, které opravňují CK k provozování jejich činnosti. Jak ukazuje obr. 2, v České republice počet CK od roku 2004 roste, k 30. 9. 2011 jich bylo evidováno 1447, což znamená růst o 47 \%. Na jednu CK tak připadá cca 7300 lidí $[4,8,11]$.

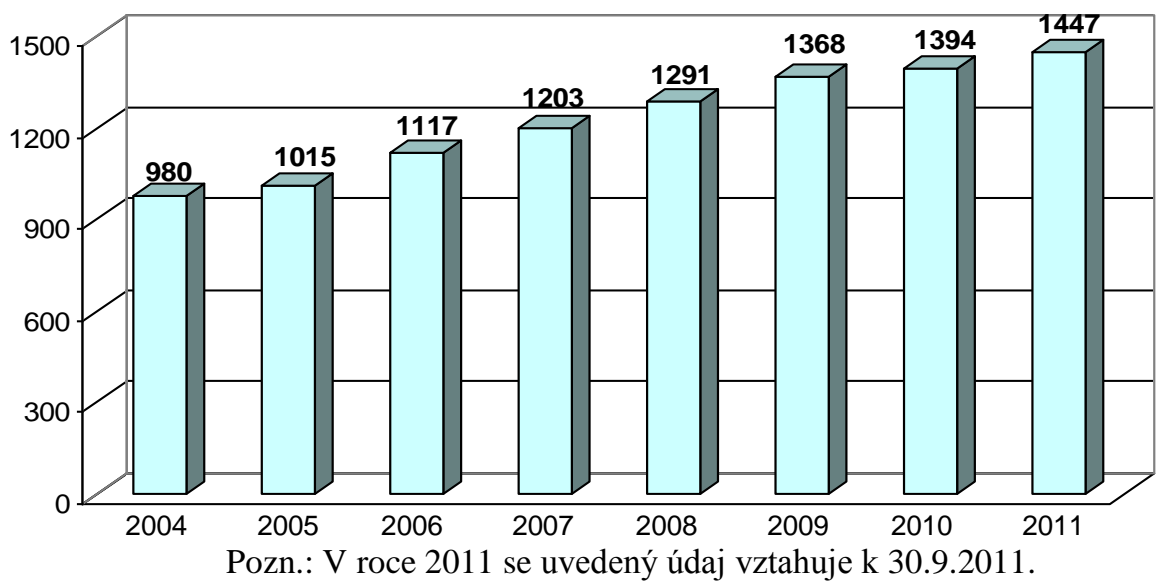

Obr. 2: Počet cestovních kanceláŕí v ČR v letech 2004 až 2011. Zdroj: [4, 8, 11] 
Z výše uvedených údajů vyplývá, že cestovní ruch je vysoce konkurenční odvětví a podnikatelské subjekty v něm nemohou nadále konkurovat pouze na základě nákladů. Měly by se proto zaměřit na spokojenost zákazníka jako klíčového elementu determinujícího konkurenceschopnost.

\section{Metodologie výzkumu}

Výzkum mezi zákazníky cestovních kancelář́ a agentur byl proveden v květnu a červnu roku 2010 v různých městech na území celé České republiky. Data byla sesbírána metodou osobního dotazování za pomocí strukturovaného dotazníku, který obsahoval široké množství otázek typu vícenásobného výběru i hodnotících škál. Respondenti byli vybráni metodou kvótního výběru na základě pohlaví a věku, přičemž byli dotazováni osoby starší 15 let, kteří v průběhu posledních dvou let využili alespoň jednou služeb CK/CA ve formě koupi zájezdu v rámci České republiky nebo do zahraničí. Při výběru respondentů byly také zohledněny současné trendy vývoje populace, a proto byl zahrnut větší podíl tzv. generace Y, kterou tvoří lidé narozeni v letech 1982 - 1993. Jedná se o výrazně ekonomicky aktivní obyvatele, v popředí jejich zájmu stojí osobní život a více si cení volného času (oproti předchozí generaci X). Zástupci generace $Y$ chtějí využít všech možností, které jim otevřená společnost a svět nabízí (tedy i cestování) a do roku 2025 budou tvořit převážnou část populace v produktivním věku [5]. Získaná data byla vyhodnocena pomocí softwaru IBM SPSS Statistics 19.

Celkem bylo dotazováno 873 respondentů, z toho $58 \%$ žen a $42 \%$ mužů. Nejvíce byla zastoupena věková kategorie 21 až 30 let (43\%) a 31 až 40 let $(20 \%)$. Lidé ve věku 15 až 20 let tvořili necelých $7 \%$, ve věku 41 až 50 let téměř $18 \%, 51$ až 60 let $8 \%$ a nejméně byli zastoupeni respondenti ve věku nad 60 let (přibližně $4 \%$ ). Podíl respondentů se středoškolským vzděláním činil $54 \%$, s vysokoškolských $23 \%$, vyučení s maturitou činili $11 \%$, vyučení bez maturity $9 \%$ a lidé se základním vzděláním $3 \%$. Z hlediska čistého měsíčního př́ijmu domácnosti byly poměrně zastoupeny všechny prř́jmové kategorie. Lidé s př́ijmem do 20000 Kč byli zastoupeni necelými $21 \%$, s př́ijmem v rozmezí 20001 40000 Kč tvořili $55 \%$ a př́ijmová kategorie nad 40000 Kč měla $24 \%$ podíl. Více jak jedna třetina $(35 \%)$ respondentů uvedla bydliště ve městech s více jak 50000 obyvateli, přibližně $65 \%$ bylo dotazováno v malých městech do 50000 obyvatel.

\section{Kvadrantová analýza}

V rámci vícedimenzionálního konceptu spokojenosti hodnotili respondenti 26 atributů pomocí hodnotící škály 1 až 5 , přičemž 1 znamenala velmi spokojen/a a 5 velmi nespokojen/a. Průměrné hodnoty atributů spokojenosti jsou uvedeny v tabulce 1 .

Výsledky spokojenosti dosahovaly průměrných hodnot 1,89 až 2,61 , což poukazuje na poměrně vysokou spokojenost. Nejvíce byli respondenti spokojení s rychlostí obsloužení a vyř́zení objednávky, se spolehlivostí a zodpovědností CK/CA a s kvalitou zakoupeného ubytování. Nejmenší spokojenost lze identifikovat u rychlosti a způsobu vyřrizení prrípadných reklamací, u vyhovění nadstandardním požadavkům a u atributu nabídky stálé pomoci (např. infolinky). 
Tab. 1: Spokojenost zákazníků CK/CA s jednotlivými atributy spokojenosti

\begin{tabular}{|c|c|c|}
\hline Atributy spokojenosti & Mean & $\begin{array}{l}\text { Std. } \\
\text { Deviation }\end{array}$ \\
\hline Rychlost obsloužení a vyřízení objednávky & 1,89 & ,820 \\
\hline Spolehlivost a zodpovědnost CK/CA & 1,91 & ,833 \\
\hline Kvalita zakoupených služeb - ubytování & 1,99 & ,884 \\
\hline Dodržení sjednaných podmínek, splnění slibů a závazků & 2,01 & ,897 \\
\hline Nabídka služeb a produktů & 2,03 & ,851 \\
\hline Kvalita zakoupených služeb - stravování & 2,07 & ,947 \\
\hline $\begin{array}{l}\text { Dostupnost a přehlednost propagačních materiálů (katalog, fotografie, video, CD, } \\
\text { DVD, web) }\end{array}$ & 2,08 & ,939 \\
\hline Atmosféra prodeje (prostředí) CK/CA & 2,08 & ,851 \\
\hline Informovanost o zakoupených službách a produktech & 2,09 & 877 \\
\hline Uživatelské prostředí webových stránek (přehlednost, obsah, funkčnost ...) & 2,09 & ,899 \\
\hline Otevírací doba CK/CA, dostupnost (počet poboček a jejich rozmístění) & 2,09 & ,908 \\
\hline $\begin{array}{l}\text { Vystupování a odbornost personálu v místě dovolené (průvodci, delegáti, řidiči, } \\
\text { animátoři, personál v hotelu) }\end{array}$ & 2,10 & ,939 \\
\hline Ochota, dojem a profesionalita pracovníků CK/CA & 2,12 & ,920 \\
\hline Cena služeb/produktů vzhledem k jejich kvalitě & 2,16 & ,859 \\
\hline Kvalita zakoupených služeb - doprava & 2,17 & ,933 \\
\hline Nabídka doplňkových služeb (letenky, víza...) & 2,17 & ,917 \\
\hline Individuální přístup ke klientovi, vstřícnost a flexibilita personálu & 2,18 & ,937 \\
\hline Kvalita doprovodných služeb (fakultativní výlety, hlídání dětí, kurzy) & 2,19 & ,905 \\
\hline Cena zakoupených služeb ve vztahu ke konkurenci & 2,21 & ,880 \\
\hline $\begin{array}{l}\text { Komunikace prostřednictvím internetu (e-mail, Skype, sociální sítě - např. Twitter, } \\
\text { Facebook, ICQ) }\end{array}$ & 2,29 & ,993 \\
\hline Kvalita a objektivnost (pravdivost) propagačních materiálů & 2,30 & ,896 \\
\hline Kvalita zakoupených služeb obdobného charakteru v porovnání s ostatními CK/CA & 2,33 & ,907 \\
\hline Snaha o navázání a udržení dlouhodobých vztahů & 2,36 & 1,088 \\
\hline Nabídka "stálé pomoci" (non stop info linka) & 2,38 & 1,141 \\
\hline Vyhovění nadstandardním požadavkům & 2,55 & 1,040 \\
\hline Rychlost a způsob vyřízení případných reklamací & 2,61 & 1,003 \\
\hline
\end{tabular}

Pozn.: 1 = velmi spokojen, 5 = velmi nespokojen

Zdroj: Vlastní zpracování.

Nestačí však pouze znát, s jakými atributy byli zákazníci nejméně spokojení, a zaměřit se pak na jejich zlepšení. Firmy musí zohlednit i ten aspekt, zda daný atribut považuje zákazník za důležitý. Jelikož pokud by firmy soustředily svoje zdroje na zlepšení takových atributů, kterým zákazníci přikládají malou váhu, nedocílily by zvýšení spokojenosti zákazníků. V této souvislosti byla provedena kvadrantová analýza, která slouží k přehlednému zobrazení jednotlivých atributů při zahrnutí dvou rozměrů. V tomto př́ípadě se jedná o rozměr důležitosti a rozměr spokojenosti. Grafickým znázorněním jsou určeny akční priority, přičemž cílem je nalézt atributy, které se nacházejí v kvadrantu ,2 - Zlepšit“" (viz obr. 3). Pokud společnost nemá dostatek zdrojů na zlepšení všech atributů, které se v tomto kvadrantu nacházejí, měla by se zaměřit na atributy s vyšší důležitostí a nižšśi spokojeností. 
Do kvadrantové analýzy však nebyly zahrnuty všechny atributy spokojenosti, nýbrž jenom ty, které tvořily faktory spokojenosti získané faktorovou analýzou $(\mathrm{KMO}=0,875, \mathrm{Sig} .=0,000)$. Jedná se o následujících 14 položek:

- vystupování a odbornosti personálu v místě dovolené

- nabídka služeb a produktů

- otevírací doba $\mathrm{CK} / \mathrm{CA}$, dostupnost

- spolehlivost a zodpovědnost CK/CA

- dodržení sjednaných podmínek, splnění slibů a závazků

- rychlost obsloužení a vyřízení objednávky

- informovanost o zakoupených službách a produktech
- rychlost a způsob vyřízení případných reklamací

- kvalita doprovodných služeb

- atmosféra prodeje $\mathrm{CK} / \mathrm{CA}$

- komunikace prostřednictvím internetu

- vyhovění nadstandardním požadavkům

- cena služeb/produktů vzhledem k jejich kvalitě

- ochota, dojem a profesionalita pracovníků CK/CA

Z hlediska důležitosti atributů hodnotili respondenti devět tzv. souhrnných atributů, tj. faktorů, které je ovlivňují při výběru CK/CA. Za účelem kompletnosti obsahoval výčet těchto souhrnných atributů i dvě položky, které byly z kvadrantové analýzy vyřazeny, a to „nezávislé informace v tisku, na internetu“ a „doporučení rodiny, prŕbuzných, známých“. U těchto dvou atributů by bylo nelogické hodnotit i úroveň spokojenosti. Proto je v kvadrantové analýze použito sedm souhrnných atributů důležitosti (viz zvýrazněné řádky v tab. 2) a 14 atributů spokojenosti jim bylo obsahově přiřazeno způsobem uvedeným v tabulce 2 . Uvedené hodnoty spokojenosti a důležitosti představují průměrné hodnoty.

Tab. 2: Hodnoty důležitosti a spokojenosti

\begin{tabular}{|c|c|c|c|}
\hline Atribut & & Důležitost & Spokojenost \\
\hline & Kvalita nabízených služeb & 2,99 & \\
\hline \multirow[t]{2}{*}{1} & Kvalita doprovodných služeb & & 2,19 \\
\hline & Cena, slevy a jiné pro zákazníky výhodné akce & 3,36 & \\
\hline \multirow[t]{2}{*}{2} & Cena ve vztahu ke kvalitě & & 2,16 \\
\hline & Dobré jméno (reputace, tradice) CK/CA na trhu & 3,78 & \\
\hline 3 & Spolehlivost a zodpovědnost CK/CA & & 1,91 \\
\hline 4 & Dodržení sjednaných podmínek, splnění slibů a závazků & & 2,01 \\
\hline \multirow[t]{2}{*}{5} & Rychlost a způsob vyřízení případných reklamací & & 2,61 \\
\hline & Sortiment nabízených služeb & 4,18 & \\
\hline \multirow[t]{2}{*}{6} & Nabídka služeb a produktů & & 2,03 \\
\hline & Srozumitelnost, dostupnost poskytovaných informací & 5,42 & \\
\hline 7 & Informovanost o zakoupených službách a produktech & & 2,09 \\
\hline \multirow[t]{2}{*}{8} & $\begin{array}{l}\text { Komunikace prostřednictvím internetu (e-mail, Skype, sociální sítě - } \\
\text { např. Twitter, Facebook, ICQ) }\end{array}$ & & 2,29 \\
\hline & Individuální přístup a profesionalita zaměstnanců & 5,98 & \\
\hline 9 & Ochota, dojem a profesionalita pracovníků CK/CA & & 2,12 \\
\hline 10 & $\begin{array}{l}\text { Vystupování a odbornost personálu v místě dovolené (průvodci, } \\
\text { delegáti, řidiči, animátoři, personál v hotelu) }\end{array}$ & & 2,10 \\
\hline \multirow[t]{2}{*}{11} & Vyhovění nadstandardním požadavkům & & 2,55 \\
\hline & Atmosféra prodeje (prostředí CK/CA, uživatelské rozhraní webu) & 6,95 & \\
\hline 12 & Atmosféra prodeje (prostředí) CK/CA & & 2,08 \\
\hline 13 & Otevírací doba CK/CA, dostupnost (počet poboček a jejich rozmístění) & & 2,09 \\
\hline 14 & Rychlost obsloužení a vyřízení objednávky & & 1,89 \\
\hline \multicolumn{2}{|c|}{ Průměrné hodnoty všech atributů } & 4,67 & 2,15 \\
\hline
\end{tabular}

Zdroj: Vlastní zpracování 
Výsledná kvadrantová analýza je uvedena na obr. 3. Osa x zachycuje důležitost (čím nižší hodnota, tím důležitější) a osa y spokojenost (čím nižší hodnota, tím vyšší spokojenost). Hodnoty vyplývají ze škál použitých v dotazníku (spokojenost 1-5, důležitost 1-9). Poloha jednotlivých bodů je určena průměrnými hodnotami důležitosti a spokojenosti u každého $\mathrm{z}$ atributů (viz výše uvedená tab. 2). Osy matice označují průměrné hodnoty důležitosti a spokojenosti u všech vlastností, tj. 4,67 pro důležitost a 2,15 pro spokojenost.

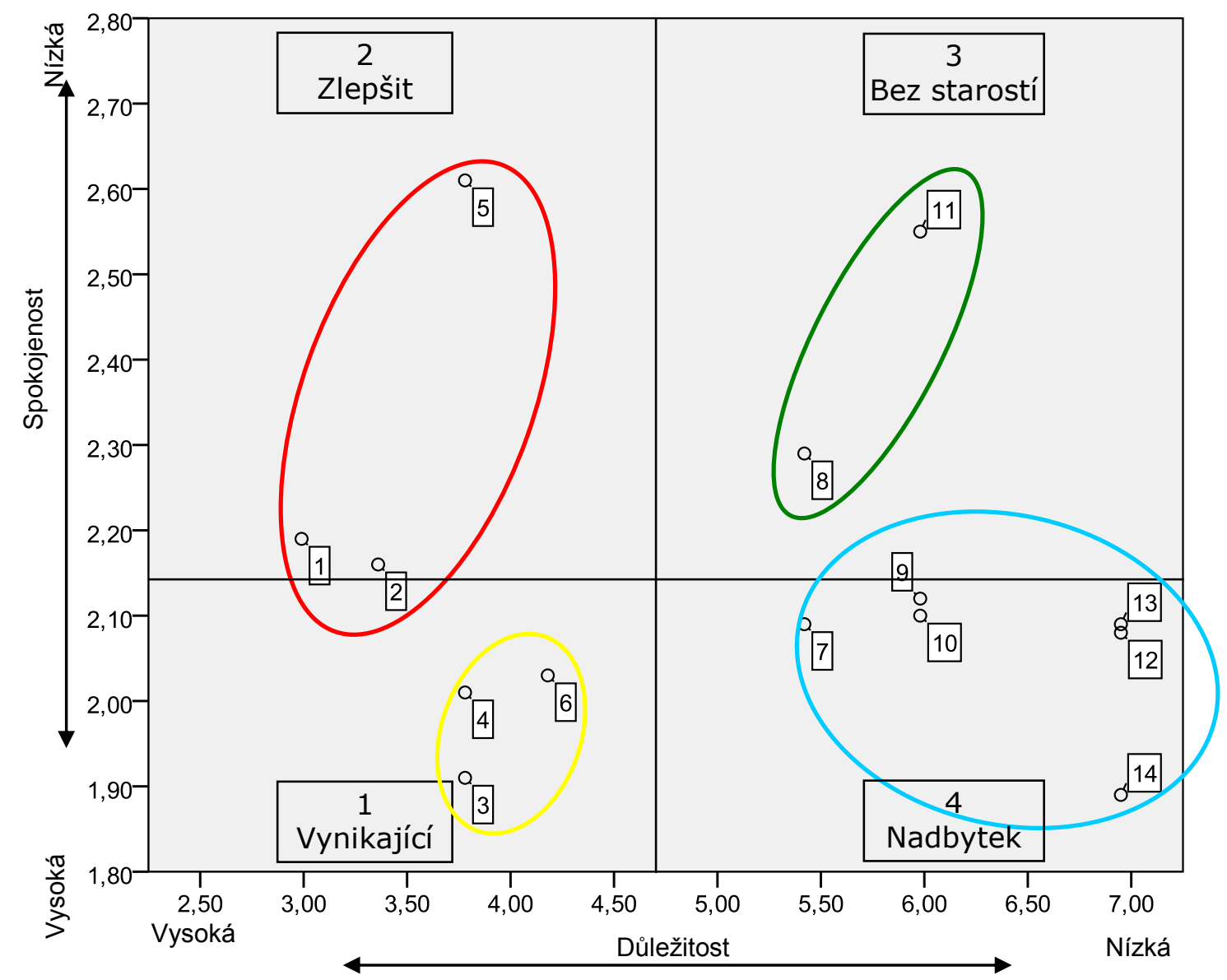

Obr. 3: Kvadrantová analýza. Zdroj: Vlastní zpracování.

Na obr. 3 se v kvadrantu „1 - vynikajíci“" nacházejí tyto atributy:

- č. 3 - spolehlivost a zodpovědnost $\mathrm{CK} / \mathrm{CA}$,

- č. 4 - dodržení sjednaných podmínek, splnění slibů a závazků a

- č. 6 - nabídka služeb a produktů.

Jedná se o atributy, které jsou pro zákazníky důležité a zákazníci s nimi byli spokojeni. Podniky by se měly soustředit na udržování, poprrípadě ještě zvyšování jejich úrovně.

V kvadrantu „2 - zlepšit“ jsou umístěny tyto atributy:

- č. 1 - kvalita doprovodných služeb,

- č. 2 - cena ve vztahu ke kvalitě a

- č. 5 - rychlost a způsob vyřízení prrípadných reklamací.

Tyto atributy jsou pro zákazníky důležité a zákazníci s nimi nebyli spokojeni, proto je třeba se $\mathrm{s}$ těmito atributy co nejdřive zabývat a alokovat zdroje na jejich zlepšení. Jen tak může být docílena vyšší spokojenost zákazníka. 
Kvadrant „,3 - bez starostí“ obsahuje 2 atributy, a to:

- č. 8 - komunikace prostřednictvím internetu a

- č. 11 - vyhovění nadstandardním požadavkům.

Z pohledu zákazníka se jedná o atributy méně důležité a zákazníci s nimi nebyli spokojeni. Pro společnosti není efektivní, aby se zlepšováním těchto atributů př́liš zabývaly, přesto však by se při dostatku zdrojů mohly snažit o zlepšení atributu č. 11, který vykazuje vysokou míru nespokojenosti a jeho zlepšení by mohlo přinést dané $\mathrm{CK} / \mathrm{CA}$ konkurenční výhodu.

V posledním kvadrantu označeném jako „4 - nadbytek“ se nachází celkem 6 atributů:

- č. 7 - informovanost o zakoupených službách a produktech,

- č. 9 - ochota, dojem a profesionalita pracovníků CK/CA,

- č. 10 - vystupování a odbornost personálu v místě dovolené,

- č. 12 - atmosféra prodeje (prostředí) $\mathrm{CK} / \mathrm{CA}$,

- č. 13 - otevírací doba CK/CA, dostupnost a

- č. 14 - rychlost obsloužení a vyřízení objednávky.

S těmito atributy byli zákaznici spokojeni, ale nepovažují je za př́liš důležité. Pro firmy představují jakýsi bonus navíc, který by mohl být rozhodující při velkém konkurenčním boji. Není však př́liš efektivní soustředit na zvyšování jejich úrovně své zdroje.

\section{Závěr}

Kvadrantová analýza ukázala, jak je rozhodující při analýze spokojenosti zahrnout i faktor důležitosti, aby nedošlo k nesprávnému alokování zdrojů za účelem zvýšení konkurenceschopnosti. Z provedeného výzkumu vyplývá, že by se CK/CA měly soustředit přednostně na rychlost a způsob vyřízení př́ípadných reklamací, cenu ve vztahu ke kvalitě a na kvalitu doprovodných služeb. Stávající úroveň by měla být udržena, popř́ípadě zlepšena u spolehlivosti a zodpovědnosti, dodržení sjednaných podmínek a u nabídky služeb a produktů. Nemá prŕliš smysl, aby se CK/CA snažily zlepšit atmosféru prodeje, dostupnost poboček (otevírací dobu) a rychlost obsloužení a vyřízení objednávky, jelikož tyto vlastnosti jsou dotazovanými považovány za spíše nedůležité. Toto zjištění mj. silně souvisí s výsledky, které byly zjištěny v rámci stejného výzkumu a charakterizují spotřebitelské chování zákazníků CK/CA. Tzv. „kamenné“ pobočky společností ztrácí svůj význam díky rozvoji informačních technologií, více jak 60 \% dotazovaných získává informace o dovolené nejčastěji na internetu a současně téměř polovina respondentů rezervuje svoji dovolenou výhradně nebo převážně prostřednictvím internetu. Výše uvedená zjištění jsou výzvou pro CK/CA, aby přizpůsobily svoji činnost měnícím se podmínkám a požadavkům zákazníků. Jen tak se mohou na vysoce konkurenčním trhu jako je Česká republika udržet.

Článek vznikl za podpory Technické univerzity v Liberci v rámci specifického vysokoškolského výzkumu SGS 3820/115.

\section{Literatura:}

[1] BIEGER, T. Tourismuslehre: ein Grundriss. 2. Aufl. Bern: Haupt, 2006, 312 s. ISBN 3-8252-2536-4.

[2] COOPER, CH., FLETCHER, J., FYALL, A., GILBERT, D., WANHILL, S. Tourism: principles and practice. 4. ed. Essex: Pearson Education, 2008, $704 \mathrm{s.}$

ISBN 978-0-273-71126-1. 
[3] KENDALL, S. D. Customer Service from the Customer's Perspective. In FOGLI, L. (ed.) Customer Service Delivery. Research and Best Practices. San Francisco: Jossey-Bass, 2006, 352 s. ISBN 978-0-7879-7620-2.

[4] Krize zvýśila zájem investorů o cestovni kancelářre [on-line]. E15, 2010. [cit. 2011-0630]. Dostupný z WWW: <http://zpravy.e15.cz/byznys/obchod-a-sluzby/krize-zvysilazajem-investoru-o-cestovni-kancelare $>$.

[5] Managing the talent crisis in global manufacturing. Strategies to attract and engage generation $Y$ [on-line]. Deloitte, 2007. [cit. 2010-04-20]. Dostupný z WWW: $<$ http://www.deloitte.com/assets/DcomGlobal/Local\%20Assets/Documents/dtt_dr_talentcrisis070307.pdf>.

[6] MINER, A., WAIN, O. Customer Service. The Dunvegan Quarterly, 1994, vol. 2, no. 1.

[7] Průzkum potřeb zákazníků pro sektor cestovních kancelář́ a agentur [on-line]. Ministerstvo pro místní rozvoj, 2010. [cit. 2010-08-08]. Dostupný z WWW: <http://www.mmr.cz/CMSPages/GetFile.aspx?guid=d16f1729-8e9d-4423-9a7c$\mathrm{d} 9 \mathrm{~b} 9455613 \mathrm{db}>$.

[8] Vývoj počtu cestovnich kancelář́ v letech 2002 - 2010 [on-line]. Mag Consulting, 2011. [cit. 2011-11-20]. Dostupný z WWW: <http://www.magconsulting.cz/article.aspx?ArticleID=878>.

[9] Zákon č. 455/1991 Sb., o živnostenském podnikání [on-line]. Česko, 1991. [cit. 2010-07-13]. Dostupný z WWW: <http://business.center.cz/business/pravo/zakony/ zivnost/>.

[10]Zákon č. 159/1999 Sb., o některých podmínkách podnikání v oblasti cestovního ruchu [on-line]. Česko, 1999. [cit. 2011-11-20]. Dostupný z WWW:

$<$ http://www.mmr.cz/CMSPages/GetFile.aspx?guid=fdceff95-6b92-4539-974f893e9760f65b>.

[11] Živnostenské podnikání v ČR I. až III. čtvrtletí 2011 [on-line]. Svaz obchodu a cestovního ruchu, 2011. [cit. 2011-11-30]. Dostupný z WWW:

$<$ http://www.google.cz/url? sa=t\&rct=j\&q=\&esrc=s\&source=web\&cd=3\&ved=0CD8QFj AC\&url=http\%3A\%2F\%2Fwww.socr.cz\%2Fassets\%2Fzpravodajstvi\%2Fstatistickoekonomicky-servis\%2Fzivno30092011 text.doc\&ei=UbTNUK3GE8bXtAaU6IHQCQ\& usg=AFQjCNG1RcsD4761VouLK8erU2_rWaRXqw\&bvm=bv.1355325884,d.Yms\&cad $=\mathrm{rja}>$.

JEL L83, M31

\section{Ing. Lenka Půlpánová}

Odborný asistent Katedra marketingu

Ekonomická fakulta

Technická univerzita $\mathrm{v}$ Liberci

Voroněžská 14, 46002 Liberec 2

Tel.: 485352412

lenka.pulpanova@tul.cz 